\title{
Tasavvuf Klasiklerinde Sohbet ve Uhuvvetin Temel İlkeleri*
}

Yrd. Doç. Dr. Mahmud Esad ERKAYA**

Atıf / (-) Erkaya, M. E. (2017). Tasavvuf Klasiklerinde Sohbet ve Uhuvvetin Temel İlkeleri, Çukurova Üniversitesi İlahiyat Fakültesi Dergisi, 17 (1), 249276.

Öz- Tasavvuf, bazı sûfîlere göre, bütünüyle âdâbdan oluşmaktadır. Bundan dolayıdır ki kişinin çevresi ve rabbi ile olan ilişkilerini düzenleyen âdâb kuralları tasavvuf edebiyatında önemli bir yer teşkil etmiştir. Tasavvuf klasikleri incelendiğinde ibadetler, sefer, konaklama, eşler arası ilişkiler, semâ, temizlik, yeme, içme, giyim kuşam, misafir ağırlama gibi pek çok konuda edeblere yer verildiği görülmektedir. Sohbet ve kardeşliğin âdâbı da bu kaynaklarda üzerinde durulan önemli bir mevzudur. Sohbet kavramı, Tasavvufta bir yandan bireyler arasındaki sevgi ve anlayış temelli birliktelik anlamındaki arkadaşlığı, diğer taraftan da dînî ve dünyevî konuların konuşulduğu ortamları ifâde etmektedir. Esas itibariyle tasavvufí eğitim, Hz. Peygamber ile ashabı arasındaki ilişki örnek alınarak sohbet metoduna dayandırılmış, mürşid ile mürid arasındaki bilgi ve edeb aktarımı birlikte yaşama suretiyle gerçekleşmiştir. Dolayısıyla mürid ile mürşid arasındaki ilişkinin sınırları ve edebleri de ayrıntılı bir şekilde kaynaklarda ele alınmıştır. Öte yandan müridin kendi seviyesindeki kimselerle arkadaşlık ve din kardeşliği âdâbı da temel bazı ilke ve esaslar tespit edilerek düzenlenmiştir. Bu bağlamda klasikleşmiş tasavvuf kaynaklarında kimlerle arkadaşlık edileceği, arkadaşı̆̆ın gayesi, şekli ve ihvân ile olan muamelelerde esas alınması gereken usule dair geniş malumat bulmak mümkündür. Bu çalışmada sohbet ve ihvân kavramları çerçevesinde mutasavvıfların birbirleriyle ve toplum ile olan ilişkilerine dair tespitler yapılacaktır.

Anahtar sözcükler- Sohbet, kardeşlik, arkadaşlık, tasavvuf, uhuvvet

\section{$\S \S \S$}

Makalenin gelişi 12.05.2017; Yayına kabul tarihi: 19.06.2017

* Bu çalışma Çukurova Üniversitesi BAP Birimi tarafından SED-2017-8257 kodlu proje kapsamında desteklenmiştir.

** Çukurova Ü. İlahiyat F. Tasavvuf Anabilim Dalı, e-posta: esaderkaya@hotmail.com 


\section{Giriş}

Tasavvuf, kul ile rabbi arasındaki ilişkiler kadar kişi ile toplum arasındaki münasebetleri de konu edinen bir ilimdir. Sefer, konaklama, eşler arası ilişkiler, semâ, temizlik, yeme, içme, giyim kuşam, misafir ağırlama gibi pek çok konuda müridin diğer insanlar karşısında nasıl davranacağı ve hangi ilkelere bağlı kalacağı bir taraftan tasavvuf büyüklerinin hayatlarında müşahede edilirken diğer taraftan da tasavvuf kaynaklarında ayrıntıları ile yer almıştır. Daha ismen ortaya çıktığı dönemlerden itibaren tasavvufun birtakım edeblerden oluşan bir ilim olduğu vurgulanmış, ${ }^{1}$ bu doğrultuda müridlerin riayet etmesi gereken edeblere dair eserler kaleme alınmıştır. Âdâbü'l-mürîdîn, edebü'lmürîd, âdâbü'l-mutasavvıfe, el-vasâya ve tarîkatnâme gibi adlarla telif edilen bu eserlerde şeyhlere intisap ederek tasavvufa girmiş olan müridlerin uymaları gereken âdâb ve erkâna dair detaylı bilgiler verilmiştir. ${ }^{2}$ Bu eserlerdeki edeb kurallarının büyük çoğunluğu yalnızca tasavvuf ehlini veya müridleri ilgilendiren kurallar olmayıp tüm müslümanların istifade edebileceği genel ahlâkî prensiplerdir. Örneğin Ebû Hâmid el-Gazzâlî’nin (ö. 505/1111) Ihyâu ulûmi'ddîn'de âyet ve hadislerden hareketle ele aldığı âdâb kurallarının tüm müslümanlara hitap ettiğini burada söyleyebiliriz. ${ }^{3}$ İşte bu çalışmada ele alacağımız

1 Örneğin Ebû Hafs el-Haddâd (ö. 260/874) tasavvufu "Tasavvuf tümüyle edepten ibarettir.” sözleriyle tanımlamıştır. Bkz. Ebü'l-Hasen Hücvîrî, Keşfu'l-mahcûb (Hakikat Bilgisi), çev. Uludağ, (İstanbul: Dergâh, 2010), s. 103.

2 Hâris el-Muhâsibî'nin (ö. 243/857) Âdâbü"n-Nüfûs ve el-Vesâyâ adlı eserleri, Yahyâ b. Muâz er-Râzî'nin (ö. 258/872) Kitâbü"I-Mürîdîn'ini, Cüneyd-i Bağdâdî'nin (ö. 298/910) Edebü'l-müftakir-ila'llah'ını, Ebû Ali Rûzbârî'nin (ö. 303/915) Kitâbü Edebi'l-fakr'ını, Hakîm et-Tirmîzî'nin (ö. 320/932) Riyâzetü'n-nefs, Âdâbü'I-mürîdîn ve Kitâbü Edebi'n-nefs adlı eserlerini, İbn Hafîf eş-Şîrâzî'nin (ö. 371/982) Kitâbü'lIktisâd'ını, Ebu'l-Kasım el-Vezzân'ın (V. asır), Edebü'l-mürîdîn'ini, Sülemî'nin (ö. 412/1021) Âdâbü's-suhbe ve hüsnül-uşre, Câmiu âdâbi's-sûfiyye, Âdâbü'l-fakr ve şerâituhû ve Beyânü zeleli'l-fukarâ ve mevâcibü âdâbihim adlı eserlerini, Tâhir b. el-Hüseyin Cassâs'ın (ö. 418/1027) Ahkâmü'l-mürîdîn'ini, Hâce Abdullah el-Ensârî el-Herevî'nin (ö. 481/1089) Muhtasar fî âdâbi's-sûfiyye'sini, Yusuf Hemedânî'nin (ö. 535/1140) Risâle Der Âdâb'ını, Necmeddin Kübrâ'nın (ö. 618/1221) Âdâbülmürîdîn, Âdâbu's-sûfiyye, Âdâbü's-sâlikîn, Âdâbü'l-mutasavvife ve Âdâbü's-sülûk ilâ Hazret-i Mâliki'l-Mülk ve Melikü'l-Mülûk adlı eserleri, Ebû Hafs Ömer esSühreverdî'nin (ö. 632/1234), Avârifü'l-maârif ve İş̧âdü'l-mürîdîn adlı eserlerini ve Muhyiddîn İbnü'l-Arabî'nin (ö. 638/1240) Âdâbü"I-mürîd adlı eserini bu bağlamda örnek verebiliriz. Bkz. Süleyman Gökbulut, "Ebu'n-Necîb Ziyâüddîn es-Sühreverdî ve Âdâbü'l-Mürîdîn Adlı Eseri”, Dokuz Eylül Üniversitesi Illahiyat Fakültesi Dergisi, 28 (2008): 144; Süleyman Uludağ, "Âdâbü'l-mürîd", TDV İslâm Ansiklopedisi (DIA), I, 336.

3 Ebû Hamid Huccetülislâm Muhammed b. Muhammed Gazzâlî, Ihyâu ulûmi'd-dîn (Beyrut: Mektebetü'l-Asriyye, 2013), II, 214 v.dğr. Ayrıca bkz. Faruk Sancar, "Gazâlî Düşüncesinde Kardeşlik ve Kardeşlik Hakları", Kutlu Doğum Haftası "Hz. 
sohbet ve uhuvvet ile ilgili öne sürülen âdâb kurallarının büyük bir bölümünün böyle evrensel ahlâk ilkeleri kabilinden ele alınabileceğini söylemek mümkündür. Bu bağlamda makalede öncelikle sohbet ve uhuvvet kavramları üzerinde durulacak, ardından tasavvuf klasiklerinden tespit edeceğimiz temel ilkeler gruplandırılarak yine bizim vereceğimiz başlıklar altında ele alınacaktır.

\section{a. Sohbet ve Uhuvvet Kavramları}

Tasavvufta sohbet (الصحبة) kavramı, Türkçe'de kullanılan sohbet kelimesinden daha geniş bir anlam alanına sahiptir. Nitekim sohbet, sözlükte, "kısa bir süre de olsa birlikte olmak, çokça mülâzemet etmek, arkadaşlık, hasbihal, dostluk, söyleşi ve bedenle ya da gönülle uzun süre beraberlik hali” gibi anlamlara gelmektedir. ${ }^{4}$ Tasavvufta ise şeyh yahut büyük âlimler ile birlikte olup onlardan mânevî anlamda feyizlenmek, onların ilimlerinden ve edeblerinden istifade etmek mânâsına gelebildiği gibi kelime anlamından hareketle çeşitli seviyelerdeki insanlarla yapılan arkadaşlık anlamına da gelmektedir. ${ }^{5}$ Nitekim sohbet kavramı tasavvufta çeşitli taksimlerle ele alınmaktadır. Söz gelimi Kuşeyrî, sohbetin üç şeklinden bahsetmektedir. Bunlardan ilki kişinin kendinden üstün olanlarla sohbetidir. Bu, özelde müridin mürşidi ile olan tasavvufî eğitime dayalı birlikteliğidir. Bunun dışında kişinin kendisinden yaşça büyük kimselerle yaptığı sohbet de bu kapsama girmektedir. Kuşeyrî, bunun esas itibariyle hizmet mahiyetinde olduğunu belirtmektedir. İkincisi kendinden aşağı olan kimselerle yapılan sohbettir. Bu da şefkat ve merhamet odaklı bir muameleyi gerekli kılmaktadır. Şefkat ve muhabbet ile muamele eden kişi, karşısındaki kimseden saygıya dayalı itaat ve hürmet görecektir. Üçüncüsü ise eşit kimselerin sohbeti/arkadaşlığıdır. Bu da îsâr ve fütüvvet üzerine binâ

Peygamber Kardeşlik Ahlakı ve Kardeşlik Hukuku" Sempozyumu (21-22 Nisan 2012), (2013).

4 Ebü'l-Kāsım Hüseyn b. Muhammed b. el-Mufaddal Râgıb el-İsfahânî, el-Müfredât fî garîbi'l-Kur'ân, haz. ed-Dâvûdî (Beyrut: Dâru'I-Kalem, 1412), s. 275; Ebü'l-Fazl Muhammed b. Mükerrem b. Ali el-Ensârî İbn Manzûr, Lisânü'l-Arab, haz. Abdullah Ali Kebir, v.dğr. (Kahire: Dâru'l-maârif, ty.), XXIV, 2401; Süleyman Uludağ, "Sohbet", TDV İslâm Ansiklopedisi (DIA), XXXVII, 350.Râgıb el-İsfahânî, elMüfredât, s. 275; İbn Manzûr, Lisânül-Arab, XXIV, 2401; Süleyman Uludağ, "Sohbet", DIA, İstanbul, 2009, XXXVII, 350.

5 Sohbet kavramının tasavvuftaki kullanımı ile ilgili ayrıca bkz. Bülent Akot, "Tasavvufî İrşad Metodu Olarak Sohbetin Fonksiyonu = Function of Gabfest as Sufistic Guidance Method", Uluslararası Sosyal Araştırmalar Dergisi = The Journal of International Social Research, VII/31 (2014): 31. 
edilmelidir. ${ }^{6}$ Çalışmada esas alacağımız anlam kişinin yapacağı her türlü arkadaşlığı kapsamakla birlikte daha çok kişinin kendi dengi olan kimselerle kuracağı arkadaşlığı içerecektir.

Ashâb ve sahabe kelimeleri de sohbet ile aynı kökten türemiş olup gramer itibariyle ism-i fâil kalıbındaki sâhib kelimesinin çoğul kipini oluşturmaktadır. Hz. Peygamber'in Mekke'den Medine'ye hicreti esnasında Sevr dağındaki bir mağaraya Hz. Ebû Bekir ile birlikte sığınmasına atıfta bulunan

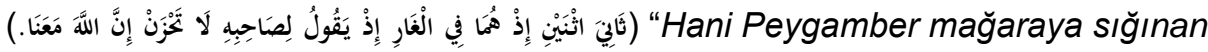
iki kişiden biri iken yanındaki can dostunu, 'Tasalanma; çünkü Allah bizimle beraber!' diyerek teselli etmişti." âyetinde geçen sâhib kelimesi aynı zamanda Hz. Peygamber'in yakın arkadaşlarını ifade eden sahabe kavramına olduğu gibi ${ }^{8}$ tasavvufun temel kavramlarından olan sohbet kavramına da kaynaklık etmektedir. Dolayısıyla Hz. Peygamber ile yapılan dostluk, arkadaşlık ve onunla uzun süre beraber yaşamayı ifade eden sahabe mefhumunun tasavvuftaki yansımasının sohbet kavramı ve metodu ile ifade edildiğini söylemek mümkündür. Nitekim Hz. Peygamber'i bir kez dahi görme imkânı elde eden herkesin sahâbî olduğu kanaatinde olan hadisçilerin aksine bir veya iki defa görmüş fakat beraber yaşama imkânı bulamamış kimselerin sahâbî sayılamayacağı kanaati fıkıh usulcülerince ileri sürülmüştür. Diğer bir deyişle usulcülere göre ancak kendisine tâbî olma gayesiyle Hz. Peygamber'le bir süre birlikte yaşama tecrübesi bulanan kimseler sahâbî kabul edilebilir. ${ }^{9}$ Usulcülerin yaklaşımlarının esası olan "uzun süre birlikte yaşama" şartı tasavvuftaki sohbet kavramının da esasını teşkil etmektedir. Bu bakımdan mutasavvıfların sohbet anlayışının fakihlerin sahâbî kavramına olan yaklaşımları ile uyum arz ettiği anlaşılmaktadır. ${ }^{10}$ Kuşeyrî’ye göre bu âyette Hz. Peygamber ve Hz. Ebû Bekir arasındaki dostluk ve arkadaşlık, tasavvuftaki sohbet kavramına tekabül et-

6 Ebü'l-Kâsım Zeynülislâm Abdülkerîm b. Hevâzin Kuşeyrî, er-Risâletü'l-Kuşeyriyye, haz. el-Mansûr (Beyrut: Daru'l-Kütübi'I-IIImiyye, 1422/2001), s. 326.

7 et-Tevbe 9/40; Kuşeyrî, er-Risâle, s. 325; Hücvîrî, Keşfu'l-mahcûb (Hakikat Bilgisi), s. 400 .

8 Bkz. Bünyamin Erul, Sahabenin Sünnet Anlayışı (Ankara: Türkiye Diyanet Vakfı Yay., 2005), s. 1.

9 Ebü'l-Hasan Seyyid Şerif Ali b. Muhammed b. Ali Cürcânî, Mu'cemü't-ta'rîfât, haz. el-Münşâvî (Kahire: Muhammed Sıddîk el-Münşâvî, ty.), s. 113; Muhammed b. A'lâ b. Ali el-Fârukî el-Hanefî Tehânevî, Mevsûatü keşşâfi ıstılâhâti'l-fünûn ve'l-ulûm, haz. el-Acem (Beyrut: Mektebetu Lübnan [Librairie du Liban], 1996), s. 1060; Erul, Sahabenin Sünnet Anlayışı, s. 5.

10 Mahmud Esad Erkaya, Kur'an Kaynaklı Tasavvuf Kavramları (Ankara: Otto, 2017), s. 119. 
mektedir. Diğer bir ifâde ile tasavvuftaki sohbet kavramı Hz. Peygamber ile ashabı arasındaki samimi ilişkiye dayanmaktadır. ${ }^{11}$

Uhuvvet (اخوة) ise kelime olarak kardeşlik anlamına gelmektedir. Sözlükte "Kardeş, arkadaş, yoldaş, dost, meslektaş ve ortak" gibi anlamlara gelen ah $\left(\dot{\tau}^{\prime}\right)$ kökü, kişinin aynı anne veya babadan dünyaya gelmesi veya sütkardeşliği sebebiyle oluşan kan bağını ifade etmekle birlikte kabile, din, zanaat, muamele, alışveriş, sevgi gibi ilişkiler vesilesiyle oluşan manevi bağı da kapsamaktadır. ${ }^{12}$ Bir görüşe göre kelimenin ihve (اخوة) şeklindeki çoğulu kan bağını, ihvân (اخوان) şeklindeki çoğulu ise mânevî bağı ifade etmek için kullanılmaktadır. ${ }^{13}$ Tasavvufta ise uhuvvet, genel anlamıyla din kardeşliği ve arkadaşlık anlamıyla kullanıldığı gibi özelde aynı tarikata bağlı olan müridlerin aralarındaki kardeşliği ifâde etmektedir. ${ }^{14}$ Bu anlayışın temeli Kur'ân'da mü'minlerden

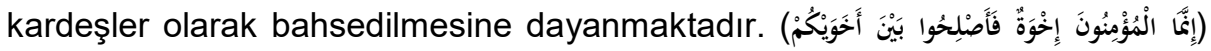
"Mü'minler ancak kardeştirler. Öyleyse kardeşlerinizin arasını düzeltin."15 âyeti başta olmak üzere Kur'ân'da yer alan pek çok âyette ${ }^{16}$ mü'minlerin kardeşliğine vurgu yapılmış olması, buna ilaveten hadislerde din kardeşliğinin öne çıkartılarak özellikle ensar ile muhacirlerin birbirleriyle kardeş ilan edilmesi ${ }^{17}$ tasavvuftaki ihvân anlayışının temellerini oluşturmuştur. Uhuvvet ve invân kavramları tasavvufta özel anlamıyla müridlerin arasındaki kardeşliği ifade etmek üzere yaygın bir şekilde kullanılmakla birlikte bu çalışmada klasik tasavvuf kaynaklarında kullanıldığı şekliyle kişinin diğer müslümanlarla olan muamelelerini de kapsayacak şekilde ele alınacaktır.

Sohbet ve uhuvvet kavramlarının özel anlamından ziyade genel anlamı esas alındığında kişinin hayatı boyunca karşılaşıp görüşeceği, belirli bir müddet vakit geçireceği din birliği olan kimseleri kasteden kavramlar olduğu görülmektedir. Dolayısıyla çalışmamızda tasavvuf kaynaklarında geçtiği şekliyle sohbet ve uhuvvet kavramları yakın anlamlı terimler olarak genel anlamları ile kullanılacak ve temel ilkeler bu bağlamda her iki kavramı da kapsaya-

ÇÜiFD, 2017, cilt: 17, sayı: 1, ss. 249-276

el-Hucurât 49/10.
Bkz. Kuşeyrî, er-Risâle, s. 325; Hücvîrî, Keşfu'I-mahcûb (Hakikat Bilgisi), s. 400.

Râgıb el-İsfahânî, el-Müfredât fî garîbi'l-Kur'ân.

Halil b. Ahmed, Kitâbü'l-ayn, haz. Hindâvî (Beyrut: Dâru'l-Kütübi'l-IIImiyye, 2003), s. 60; İbn Manzûr, Lisânü'l-Arab, I, 40.

Süleyman Uludağ, "İhvan”, TDV İslâm Ansiklopedisi (DIA), XXI, 580.

Örneğin bkz. Âl-i İmrân 3/103; et-Tevbe 9/11; el-Haşr 59/10.

Buhârî, I'tisâm, 16, no. 7340; Ebû Dâvûd, Ferâiz, 17, no. 2926. 
cak şekilde belirlenecektir. Buna ilaveten yeri geldikçe özel anlamları ile ilgili esaslara da değinilecektir.

\section{b. Temel İlkeler}

Tasavvuf klasiklerinde müridin gerek şeyhi ile gerekse diğer müridlerle olan münasebetleri ayrıntılı bir şekilde edeb kuralları çerçevesinde ele alındığı gibi müridin arkadaşıı etmesi muhtemel tüm müslümanlarla gerçekleşmesi beklenen ideal ilişki şekli de kapsamlı bir şekilde yer almaktadır. Bu bağlamda kaynaklarda kimlerle arkadaşlık edileceği, arkadaşlığın gayesi, şekli, ihvân ile olan muamelelerde esas alınması gereken usule dair geniş malumat bulmak mümkündür. ${ }^{18}$ Burada klasik tasavvuf kaynaklarından hareketle sohbet ve uhuvvete dair temel ilkeler tespit edilecektir. Tespitlerde tasavvuf klasikleri arasında âdaba dair önemli bilgiler veren Serrâc'ın (ö. 378/988) elLüma' fî târîhi't-Tasavvufi'l-İslâmî adlı eseri, Ebû Tâlib el-Mekkî'nin (ö. 386/996) Kûtü'l-kulûb'u, Hücvîrî'nin (ö. 465/1072) Keşfu'l-mahcûb'u, Kuşeyrî̀nin (ö. 465/1072) er-Risâle'si, Gazzâlî'nin (ö. 505/1111) Ihyâu ulûmi'ddîn'i, Ebü'n-Necîb es-Sühreverdî'nin (ö. 563/1168) Âdâbü'l-mürîdîn'i ve Ebû Hafs es-Sühreverdî'nin (ö. 632/1234) Avârifü'l-maârif aldı eseri temel alınacaktır.

Söz konusu eserlerden el-Lüma'da sohbet adabına müstakil bir bölüm ayırılmıştır. Serrâc, burada umumiyetle sûfîlerin sözlerini ve başlarından geçen ibretlik olayları zikretmekle yetinmiş, sohbetin ilkelerine dair çıkarımlar yapmamıştır. Bununla birlikte muhtevası yönünden kendisinden sonraki dönemde yazılan eserlere tesiri olmuş, sohbet konusunda Serrâc'a atıfta bulunulmuştur. Bu atıflarda kimi zaman Serrâc'ın konu ile ilgili sözlerine ismi de zikredilerek değinilmiş, kimi zamansa naklettiği diğer sûfîlerin hikmetli sözlerine yer verilmiştir. Bu yönüyle Serrâc'ın el-Lüma'sının kendisinden sonraki dönemde kaleme alınan eserlere kaynaklık teşkil etmiş olduğu görülmektedir.

18 Sohbet âdâbı tasavvuf tarihi boyunca muhtelif sûfî müellifler tarafından kaleme alınmış, sohbetin önemi ve nasıl icra edilmesi gerektiği ayrıntılarıyla kayda geçmiştir. Bu bağlamda yapılan bazı çalışmalar için bkz. Ahmet Ögke, "Oğlanlar Şeyhi İbrâhim Efendi'ye Göre Sohbet Âdâbı", Islâmî Araştırmalar Dergisi, XVII/1 (2004): 86; Müzeyyen Altunbay, "Erzurumlu İbrahim Hakkı Hazretleri ve Marifetnâme'de Sohbet Adabı", Bütün Yönleriyle Erzurumlu Ibrahim Hakkı Hazretleri Sempozyumu (16-18 Kasım 2011 Erzurum) Bildiriler, (2012), s. 96; Safi Arpaguş, "Tasavvuf Kültüründe Kardeşlik Algısı", Kutlu Doğum Haftası "Hz. Peygamber Kardeşlik Ahlakı ve Kardeşlik Hukuku" Sempozyumu (21-22 Nisan 2012), (2013); Safi Arpaguş, "Alvarlı Hâce Muhammed Lutfî'nin Dîvân'ında Bir Seyr u Sülûk Metodu Olarak Sohbet", Uluslararası Hâce Muhammed Lutfî (Alvarlı Efe) Sempozyumu (25-26 Nisan 2013, Erzurum) Bildiriler, (2013). 
Öte yandan Serrâc'ın çağdaşı Ebû Tâlib el-Mekkî de, Kûtü'l-kulûb'da sohbet ve uhuvvete geniş bir yer ayırmış, burada kardeşliğin mahiyeti, önemi, arkadaş seçimi, arkadaş ile geçimin nasıl olması gerektiği, arkadaşı yalnızca Allah için sevmek, ona karşı ihlaslı olmak gibi sohbet ve uhuvvette dikkat edilmesi gereken hususlar üzerinde durulmuştur. Mekkî'nin, Serrâc'a göre konuyu çok geniş bir şekilde ele aldığı görülmektedir. Makalede çıkardığımız temel ilkeler de büyük oranda Mekkî'nin eserinde yer alan bilgilerden elde ettiğimiz veriler doğrultusunda şekillenmiştir. Kendisinden sonra yazılan eserlerde de benzer konuların ele alındığı düşünüldüğünde Mekkî’nin konuyu geniş bir şeklide ele almış olmasının kendisinden sonraki sûfîlere tesir etmiş olabileceğini göstermektedir. Bu tesir büyük oranda Gazzâlî'de görülmektedir. Nitekim Gazzâlî de Mekkî'de olduğu gibi İhyâu ulûmi'd-dîn'de ülfet ve uhuvvetin faziletine geniş bir bölüm ayırmıştır. Burada öncelikle uhuvvetin önemine dair âyet ve hadislere yer vermiş, ardından dostluğun dünyalık merkezli olmaması gerektiğini vurgulayarak arkadaşlık edilecek kimsede bulunması gereken vasıflar üzerinde durmuş ve son olarak arkadaşların birbirleri üzerindeki haklarından bahsetmiştir. Burada şu hususu da belirtmeliyiz ki kendisinden önce kaleme alınmış tasavvuf klasikleri ile karşılaştırıldığında Gazzâlî'nin eserinin daha sistemli ve geniş bir şeklide konuyu ele almış olduğu hemen görülmektedir.

Sûfîlerin sohbetteki âdâbına dair müstakil bir bölüm ayıran sûfîlerden birisi de Hücvîrî'dir. Hücvîrî, Keşfu'l-mahcûb'unda âyet ve hadislerden örnekler vererek sohbetin önemini vurgulanmış, sonrasında sûfîlerin konu ile ilgili sözlerine yer vermiştir. Hücvîrî, konuyu Serrâc'dan daha detaylı ele almakla birlikte Mekkî ve Gazzâlî kadar geniş açıklamalarda bulunmamıştır. Hücvîrî ile çağdaş sûfîlerden Kuşeyrî ise er-Risâle'de sohbet konusuna ayrı bir bölümde yer vermiş, âdeti olduğu üzere verdiği bir-iki âyetin ardından sûfîlerin sözlerine geçmiştir. Konuyu yaklaşık olarak Hücvîrî ile aynı hacimde ele almış, konuyu sûfîlerin söz ve davranışları özelinde aktarmıştır. Kuşeyrî buna ilaveten kendi hayatından da örnekler vererek müridin şeyhi ile arkadaşığının nasıl olması gerektiği konusunda önemli bilgiler vermiştir.

Ebü'n-Necîb es-Sühreverdî de Âdâbü'l-mürîdîn adlı eserinde sohbet âdabına yer vermektedir. Burada öncelikle sohbetin çeşitlerinden bahseden Sühreverdî, muhatabın seviyesine göre sohbetin şeklinin ayarlanması gerektiğini vurgulamaktadır. Bunun yanında vücuttaki her azanın kendisine ait bir edebi bulunduğunu ifâde eden Sühreverdî, sonrasında ise arkadaşlığın öneminden bahsetmektedir. Muhataba göre sohbetin şeklinin değişmesi yönün- 
deki açıklamaları ve her azaya özel bir edebden bahsetmesi Sühreverdî’yi diğer sûfîlerden ayırmaktadır.

Ebû Hafs es-Sühreverdî ise Avârifü'l-maârifte sohbet ve uhuvvetin âdâbı konusuna bir bölüm ayırmış, arkadaşığın doğru bir şekilde yürütülmesi için gerekli kurallardan bahsetmiştir. Sühreverdî'nin bahsettiği edeb kurallarının burada tespit ettiğimiz ilkelerin büyük bir kısmına kaynaklık teşkil ettiğini söyleyebiliriz. Bu bakımdan kendisinden önceki kaynaklardaki muhtevayı veciz bir şekilde içerdiğini söylemek mümkündür.

Söz konusu tasavvuf klasiklerinde sohbet ve uhuvvet kavramları çoğu zaman birbirlerinin yerine kullanılmıştır. Aynı konular kimi zaman uhuvvet kimi zamansa sohbet başlığı altında ele alınmıştır. Bu kavramlarla kişinin kendi seviyesindekilerle, kendisinden aşağıdakilerle ve kendisinden üst seviyelerdeki kimselerle yaptığı dostluk ve arkadaşlık ifâde edilmiştir. Bunun yanında özel olarak müridin şeyhi ile ilişkilerini kastetmek için sohbet, müridlerin birbirleriyle olan ilişkileri için ise uhuvvet kavramının kullanıldığı görülmektedir. Sohbet ve uhuvvet bağlamında esas alınan temel ilkeler, söz konusu kaynaklarda dağınık olarak yer almış, kimi zaman bir sûfînin hayatından bir kesit olarak sunulmuş, kimi zamansa hikmetli bir söz olarak vurgulanmıştır. Bizim burada yapacağımız, kaynaklarda dağınık halde olan ilkeleri tespit ederek belirleyeceğimiz başlıklar altında değerlendirmek olacaktır.

Klasik tasavvuf kaynakları incelendiğinde üzerinde önemle durulan hususlardan ilkinin doğru arkadaş seçimi mevzusu olduğu görülmektedir.

\section{Doğru Arkadaş Seçimi}

Doğru arkadaş seçimi, insanlar arası ilişkilerde yalnızca sûfîlerin değil, her müslümanın esas alması gereken temel bir ilkedir. Nitekim Hakk'ın rızasına uygun samimi bir dostluğun kurulabilmesi doğru arkadaş seçmekten

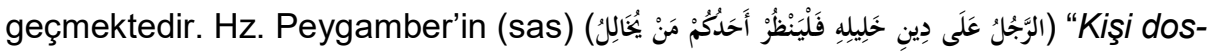
tunun dini üzeredir. Bu yüzden her biriniz, kiminle dostluk ettiğine dikkat etsin." ${ }^{19}$ hadisi uyarınca sûfîler doğru arkadaş seçimine dikkat etmişlerdir. Onlara göre bir kimsenin iyi insanlarla dostluk kurması durumunda, kendisi kötü bile olsa zamanla arkadaşları vesilesiyle iyileşmesi mümkündür. Öte yandan şerli kimselerle arkadaşlık edenin, kendi halinin de zamanla kötüleşmesi muhtemeldir. Zira onlarla birlikte olmak, kötülüğe rıza gösterdiği anlamına da gelmektedir. Kötülüğe rıza göstermek ise kişiyi zamanla bulunduğu halden daha

19 Tirmizî, Zühd, 45, no. 2378; Ebû Dâvûd, Edeb, 16, no. 4833. 
aşağı bir konuma sevk edecektir. ${ }^{20}$ Bunun için arkadaşlık edilecek kimsenin, kişinin dünyasını ve ahiretini mamur edecek bir kişiliğe sahip olması önemli görülmektedir.

Doğru arkadaş seçimine dair sûfîlerin belirlediği bazı kıstaslar bulunmaktadır. Söz gelimi Ebû Tâlib el-Mekkî'ye göre üç kimseyle arkadaşlık kurulmaz:

a. Bidat sahibi ile

b. Açıkça günah işleyen fasık ile

C. Sırf dünyalık menfaatler için zenginlerle dostluk kuran fakir ile ${ }^{21}$

Ebû Tâlib el-Mekkî̀nin belirlediği bu ölçütler arkadaşlığın ancak dindar kimselerle yapılması gerektiğini göstermektedir. Aynı hususu Gazzâlî (ö. 505/1111) de dile getirmekte ve arkadaşlık edilecek kişide beş vasfın bulunması gerektiğini belirtmektedir:
a. Akıllı olmak
b. Güzel ahlâk sahibi olmak
c. Fasık (günahkâr) olmamak
d. Bidat sahibi olmamak
e. Dünyalığa karşı hırslı olmamak22

Gazzâlî̀nin vurguladığı bu vasıflardan, sohbet ve kardeşlik edilecek kimsenin öncelikle dinin hükümlerine riayet etmesi ve bunun neticesi olarak da ahlâkını güzelleştirmiş olması gerektiği anlaşılmaktadır. Sûfîler sağlam bir imanı ve dine uygun ameli bulunmayan kimsenin gerçek bir arkadaş hatta aile ferdi dahi olamayacağı kanaatindedirler. Bu düşüncelerini Hz. Nuh'un iman etmeyen oğlu hakkında Kur'ân'da "Ey Nûh! O, asla senin âilenden değildir."23 buyurularak oğlunun Hz. Nuh'un ehlinden sayılmayacağını bildirmesinden

20 Hücvîrî, Keşfu'l-mahcûb (Hakikat Bilgisi), s. 399.

21 Muhammed b. Ali b. Atıyye el-Hârisî Ebû Tâlib el-Mekkî, Kûtü'l-kulûb fî muâmeleti'l-mahbûb ve vasfu tarîki'l-mürid ilâ makami't-tevhid, haz. ed-Derkâvî (Beyrut: Dâru'l-Kütübi'I-İlmiyye, 2009), II, 370.

22 Gazzâlî, İhyâu ulûmi'd-dîn, II, 231.

23 Hûd 11/46. 
çıkartmaktadırlar. ${ }^{24}$ Bunun için sûfîler arkadaşın itikat ve dini hükümler konusunda bilgi ve amel sahibi olmasına büyük önem vermektedirler.

Şehabeddin es-Sühreverdî arkadaşı kişinin halini yansıtan bir aynaya benzeterek onunla dostluk kurmayı kendisini muhasebe etmesi için bir vasıta olarak değerlendirmektedir. Sühreverdî’ye göre müridde bir kimse ile arkadaşlık kurma hissi yahut bir meyil oluştuğunda öncelikle karşısındakinin haline bakmalıdır. Eğer o kimse iyi huylu, güzel hal sahibi bir kimse ise bu aynı zamanda kendisinin halinin güzel olduğuna dair bir işarettir. Nitekim mü'min mü'minin aynası olması hasebiyle o şahısta kendi halinin bir yansımasını görmüş olacaktır. Bunun tam tersi de mümkündür. Eğer muhabbet edilen kimsenin davranışları ve durumu kötü ise öncelikle kendisini kınamalı ve o şahıstan uzaklaşmalıdır. Çünkü böyle bir kimse ile dostluk kurulması halinde her iki tarafın da düzelmesi zor olacaktır. Dolayısıyla mürid öncelikle kendi halini düzeltmeli, sonra arkadaşına yönelmelidir. Meyledilen kimsenin hali güzel ise ve onunla beraber olmaya dikkat edilirse kendi halinin de güzel olacağını anlamalıdır. Fakat bu durum her zaman bu şekilde cereyan etmeyebilmekte ve mürid fâsık kimselerden ziyade sâlih görünenlerden zarar görebilmektedir. Çünkü fâsık kimselerin kim olduğu zahiren ortadadır ve ona göre tedbir almak mümkündür. Fakat sâlih görünen münafık kimseler ile yapacağı sohbet ve arkadaşlık neticesinde tabii olarak aralarında etkileşim ve müridin halinde bozulmalar görülebilecektir. Bunun için mürid, uyanık olmalı ve kendisini Allah'ın rızasından uzaklaştıracak her türlü arkadaşlıktan uzak durmalıdır. 25

Sühreverdî’nin arkadaşlık kurmaya yüklediği bu fonksiyon, ele aldığımız diğer tasavvuf kaynaklarında bulunmayan orijinal bir yorumdur. Bu şekliyle arkadaşlık, kişinin kendisine çeki düzen verebilmesi için önemli bir kıstas olarak değerlendirilmiştir. Bunu günlük hayatta test etmemiz mümkündür. Nitekim kişi ancak kendi karakterine uygun olan kimselerle arkadaşlık etmek isteyecektir. Örneğin dürüst bir kimse ancak kendisi gibi dürüstlerle arkadaşlık edecek, bunu aksine kötü karakterli kimseler ise kendi mizacına uygun kimselerle dostluk edecektir. Dolayısıyla kişinin arkadaşına bakarak kendisine çeki düzen vermesi mümkündür. Münafık kimselerle yapılacak dostlukta ise ölçü Allah'ın emir ve yasakları olacaktır. Bu durumda Allah'a asi olan kimselerle

24 Ziyâüddîn Abdülkahir b. Abdillâh Ebü'n-Necîb es-Sühreverdî, Âdâbü'l-mürîdîn, haz. Asım İbrahim el-Keyyâlî (Beyrut: Dâru'l-Kütübi'l-IIImiyye, 2013), s. 34. 
dostluk kurmak uygun bir davranış olmayacaktır. Dolayısıyla Sühreverdî'nin bu anlayışının pratik bir karşılığı bulunmaktadır.

\section{Samimiyet}

Sağlam bir arkadaşlığın gerçekleşmesi için tarafların birbirlerine karşı samimi olması gerekir. Mürid, arkadaşının yanında yahut gıyabında her ne zaman olursa olsun onu savunmalı, ona karşı içi dışı bir olmalıdır. Sûfîler samimiyetin ölçüsünü kişinin arkadaşına dair tavır ve davranışlarında onun varlığının ve yokluğunun bir olmasına bağlamaktadırlar. Onlara göre kişinin, arkadaşının gıyabında ya da yanında iken halinde bir değişiklik yoksa bu arkadaşlık samimi bir arkadaşlık demektir. Eğer bu iki durumda, kişinin halinde farklılık oluyorsa burada samimiyetsizlik ve yağcılık olduğu açıktır. ${ }^{26}$

Sağlıklı bir arkadaşlığın kurulup sürdürülebilmesi için taraflar, birbirlerinin arkasından hainlik yapmamalı, birbirlerini sevmedikleri şekilde yanlarında veya gıyaplarında anmamalı, birbirlerine hiçbir surette yalan söylememeli, birbirlerini özür dileme veya idare etme durumuna düşürmemeli ve muhatabını gücünün yetmeyeceği yahut yapmak istemeyeceği işleri yapmak durumunda bırakmamalıdır. ${ }^{27}$

Samimiyet ilkesi günümüz arkadaşlık ilişkilerinde eksikliği hemen sezilen bir ilkedir. İkiyüzlülük, kişinin yanında başka arkasında başka konuşma ve koğuculuk gibi davranışlar arkadaşlar arasındaki güven duygusunu zedelediği gibi dostluğun kısa ömürlü olmasına da sebebiyet vermektedir. Bu bakımdan sûfîlerin üzerinde önemle durduğu bu ilkenin evrensel bir ilke olduğu görülmektedir.

\section{Allah'ın Rızasını Kazanmak}

Arkadaşlığın kurulması ve sürdürülmesinde esas gaye Allah'ın rızasını kazanmak olmalıdır. Nitekim Hücvîrî sûfînin sohbet konusundaki vasıflarını sayarken şu hususları vurgulamaktadır: Sufi kimseyi küçümsemez, yaşlılara hürmet göstererek onları baba mesabesinde görür, yaşıtlarını kardeşleri gibi görerek onlara içten ve samimi bir şekilde davranır, küçüklere ise evlatları gibi şefkatle muamele eder. Sûfî kin, haset, hıyanet, gıybet, nefret ve düşmanlık duygularından mümkün olduğunca kaçınarak herkese samimi davranır. Nitekim onlara göre arkadaşlık Cenâb-ı Hakk'ın rızasını kazanma gayesiyle kuru-

\footnotetext{
26 Ebû Tâlib el-Mekkî, Kûtü'l-kulûb, II, 366.

27

Ebû Tâlib el-Mekkî, Kûtü'l-kulûb, II, 376.
}

ÇÜiFD, 2017, cilt: 17, sayı: 1, ss. 249-276 
lur. Bunun içindir ki kuldan sadır olan hatalı söz ve fiiller Hak rızası için kurulan arkadaşlığı bozamaz. ${ }^{28}$

$\mathrm{Bu}$ ilke samimiyet ilkesiyle doğrudan alakalıdır. Kişinin arkadaşına karşı samimi olmasında en büyük etken bu arkadaşlığın dünyevî menfaatler doğrultusunda değil Allah rızasını kazanmak için kurulmuş olmasıdır. Diğer bir deyişle Allah'ın rızasını kazanma düşüncesiyle kurulan dostluklarda samimiyetsizlik ortadan kalkacaktır.

\section{Güven}

Arkadaşığın sürdürülmesinde tarafların karşılıklı olarak birbirlerine güven duymaları önemli bir etkendir. Öyle ki tasavvuf kaynaklarında üzerinde sıklıkla durulan hususlardan birisi de arkadaşlığın güven üzerine kurulmasıdır. Kiminle sohbet edilmesi gerektiği kendisine sorulduğunda bir sûfî temel ilkeyi şöyle dile getirmiştir: “'Kalk gidelim.' denildiğinde 'Nereye?' diyorsa, o kimse gerçekten arkadaş değildir." ${ }^{29}$ Bu söz tasavvuf kaynaklarının hemen hepsinde arkadaşlığın âdâbı arasında sayıımış, arkadaşı tarafından çağırıldığında "Nereye?", "Niçin?", "Hangi sebeple?" gibi sorular yöneltmeme kuralı arkadaşlığın temel ilkelerden birisi haline gelmiştir. ${ }^{30}$

Bu şekilde güven merkezli bir arkadaşlığın kurulması, tarafların, doğu arkadaş seçimi ilkesinde belirttiğimiz akıllı olmak, güzel ahlâk sahibi olmak, fasık (günahkâr) olmamak, bidat sahibi olmamak ve dünyalığa karşı hırslı olmamak gibi vasıfları haiz olmalarından geçmektedir. Ancak bu vasıfları taşıyan arkadaşlar birbirlerine mutlak anlamda güven duyabilecektir. Aksi takdirde karşılıklı güvensizlik oluşacak ve neticede arkadaşlık yürümeyecektir. Öte yandan böyle bir arkadaşlığın kurulabilmesi için kişinin her türlü şahsi menfaatten geçerek arkadaşını kendisine tercih etmesi gerekmektedir. Her hal ve hareketinde arkadaşını öncelediğinde kendisi aleyhinde olabilecek durumları önemsemeyecek, böylece arkadaşından gelen her türlü ezaya katlanabileceği şuurunda olacaktır. Böylece arkadaşının isteği doğrultusunda hareket etmek ona ağır gelmeyecektir. Fakat güvenin bu boyutunu içeren bir arkadaşlık günümüz insanı düşünüldüğünde neredeyse imkânsızdır. Nitekim artık kişinin değil arkadaşına, en yakınına dahi bu düzeyde bir güveni kalmamıştır. Bunda yukarıdaki vasıfları taşıyacak gerçek arkadaşların azalması ve îsâr duygusu-

Hücvîrî, Keşfu’l-mahcûb (Hakikat Bilgisi), s. 401.

Ebû Nasr Abdullah b. Ali et-Tûsî Serrâc, el-Lüma' fî târîhi't-Tasavvufi'l-İslâmî, haz. el-Hindâvî (Beyrut: Dâru'l-Kütübi'l-İlmiyye, 2007), s. 163. 
nun tasavvuftaki boyutuyla benimsenmemiş olmasının önemli bir etkisinin olduğu düşünülebilir. Bu bakımdan söz konusu ilkenin günümüz için biraz esnetilmesi daha uygun olacaktır. Zira genel anlamda güven duygusunun esas alındığı bir arkadaşlık modeli dahi arkadaşlığın sağlam temeller üzerine bina edilmesi için kifayet edecektir.

\section{Tevâzû}

Arkadaşlıkta muhatabın hiçbir zaman küçümsenmemesi önemli bir ilkedir. Bu ilke doğrultusunda yaşlılar gençleri, yaşlarından ötürü az günah işlemiş oldukları düşüncesiyle üstün görmelerinin gerektiği belirtilmiştir. Aynı şekilde gençlerin de, yaşça kendilerinden büyük olanları, ibadete ve hizmete daha evvel başlamış olmaları hasebiyle kendilerinden üstün görmeleri gerektiği ifâde edilmiştir. Böylece kişideki kibir ve üstünlük düşüncesi yok olacaktır. 31

Bu ilkede sûfîlerin tevâzûyu dini temeller üzerinde günah-sevap düzeyinde yorumladıkları görülmektedir. Fakat bunu diğer alanlara da teşmil ederek hayatın bütününde kişinin arkadaşlarına karşı tevâzûyu elden bırakmaması şeklinde anlamak da mümkündür.

\section{6. Şefkat}

Mü'minlerin birbirlerine karşı sabır ve merhamet dairesinde ilişki kurmaları âyetlerde ifâdesini bulunan önemli bir vasıftır. ${ }^{32}$ Örneğin Beled sûresinde (وَتواصَوْا بِالصَّبْرِ وَتَواصَوْا بالمَرَمَمَّة) buyurularak mü'minlerin "birbirlerine sabır ve merhameti öğütleme"sinin gerekliliği vurgulanmaktadır. ${ }^{33}$ Bunun için arkadaşların birbirleri ile münasebeti sabır ve şefkat üzerine kurulmalıdır. ${ }^{34}$ Sûfîlere göre Sevr mağarasında Hz. Peygamber (sas) ile Hz. Ebû Bekir'in arasında geçen diyalog arkadaşlığın şefkat ile nasıl yürütüldüğünün güzel bir örneğidir.

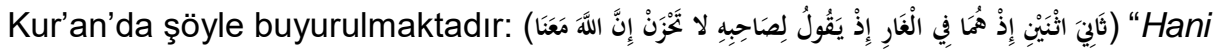
onlar mağarada bulunuyorlardı. Hani o, arkadaşına, 'Üzülme, çünkü Allah bizimle beraber' diyordu." 35 Ayette öncelikle Hz. Ebû Bekir için Hz. Peygamber'in arkadaşı olarak bahsedilmektedir. Bundan dolayı tasavvuftaki sohbet

31 Hücvîrî, Keşfu'l-mahcûb (Hakikat Bilgisi), s. 403.

32 Bkz. el-Mâide 5/54; el-Fetih 48/29.

33 el-Beled 90/17.

34 Kuşeyrî, er-Risâle, s. 325; Hücvîrî, Keşfu’l-mahcûb (Hakikat Bilgisi), s. 400; Ebû Tâlib el-Mekkî, Kûtü'l-kulûb, II, 372; Ebû Hafs es-Sühreverdî, Avârifü'l-maârif, s. 239, 240.

35 et-Tevbe $9 / 40$. 
kavramı bu âyete isnad edilmektedir. Hz. Peygamber'in arkadaşını “Üzülme, çünkü Allah bizimle beraber" şeklinde teskin etmesi ise şefkatli bir arkadaşın tesellisi olarak yorumlanmaktadır. ${ }^{36} \mathrm{~Hz}$. Peygamberin örnek hayatında olduğu gibi arkadaşlık ilişkilerinde mü'milerin şefkat ve merhamet odaklı bir yaklaşım sergilemeleri sûfîlerin önemsedikleri bir husus olmuştur.

\section{Bilgi Paylaşımı}

Arkadaşların birbirlerine karşı yerine getirmeleri gereken vazifelerden birisi de ilim bakımından birbirlerinin eksiklerini tamamlamalarıdır. Sûfîlere göre bir kimse ilim bakımından kendisinden daha üstün veya aşağıda olan kimselerle arkadaşlık edebilir. Bu arkadaşlıkta kişi kendisinden üstün olan kimsenin ilminden istifade etmeyi, kendisinden aşağıda olan kimseyi ise ilmî anlamda faydalandırmayı esas almalıdır. Nitekim Peygamber (sas) şöyle buyurmaktadır: (إن من تمام التقوى تعليم من لا يعلم) "Bilgisiz bir kimseye bilgi vermek takvânın kemâlindendir." ${ }^{37}$ Bu rivâyet, takvânın tamam olmasını insanlara ilim öğreterek faydalı olmaya bağlamaktadır. Takvânın Allah'a karşı kulluk sorumluluğunu yerine getirmek olduğu düşünüldüğünde, insanlara yararlı olmanın kişinin sorumlulukları arasında sayıldığı anlaşılacaktır. Bu şekilde gerçekleşen bir arkadaşlık aynı zamanda toplumun bilgi düzeyini de arttıracaktır.

\section{Muhatabın Seviyesini Dikkate Alma}

Arkadaşlığın ilkelerinden biri de herkesle seviyesine göre muamele etmektir. İnsan hayatı boyunca her türlü insanla az ya da çok vakit geçirerek arkadaşlık münasebeti kurabilmektedir. Bu ilişkilerinde muhatabın seviyesine göre davranması, arkadaşlığın sürdürülmesi açısından önemli bir husustur. Bundan dolayı tasavvuf kaynaklarında hangi insanlarla nasıl muamele edilmesi gerektiği hususunda önemli ilkelerden bahsedilmektedir. Söz gelimi Ebû Hafs el-Haddâd'a (ö. 260/874) sohbetin âdâbı sorulduğunda şu ilkeleri saydığı nakledilmektedir:
a. Şeyhlere/yaşlılara hürmet etmek
b. İhvân ile güzel muamele etmek
c. Küçüklere nasihat etmek
d. Kendi seviyesinde olmayanlarla sohbeti terk etmek
e. İsâr ile muamele etmek

36 Kuşeyrî, er-Risâle, s. 325; Hücvîrî, Keşfu'l-mahcûb (Hakikat Bilgisi), s. 400.

37 Hücvîrî, Keşfu'l-mahcûb (Hakikat Bilgisi), s. 399. Rivayet, bilebildiğimiz kadarıyla hadis kaynaklarında yer almamaktadır. 


\section{f. Biriktirmekten kaçınmak}

g. Dini ve dünyevî meselelerde yardımlaşmak. ${ }^{38}$

Benzer ilkeler diğer sûfîler tarafından da dile getirilmiştir. Ebü'n-Necîb es-Sühreverdî'nin ifâde ettiğine göre sohbet, büyük ve yaşlı kimselerle saygı ve hürmetle, akranlarla güler yüz, güzel söz ve insân ile memnun edecek şekilde, küçüklerle ise şefkatle onları irşad etme ve eğitme suretinde gerçekleşir. Bunun dışında toplumun çeşitli kesimlerinden kimselerle nasıl muamele edileceği de anlatılmış, mürşidlerle sohbet ise daha detaylı bir şeklide ele alınmıştır. Özetle mürşidlerle sohbet onların emir ve yasaklarına riayet etme şeklinde gerçekleşir ki bu hakikatte hizmet olarak tezahür etmektedir. ${ }^{39}$ Ayrıca müridin faziletini bildiği kişilere ayrıca hürmet göstermesi de gereklidir. ${ }^{40}$

Hizmetçilerle olan muamele, lütuf ve hoşgörü ile yapılır. Gariplerle olan sohbet güler yüz, sevgi ve edeble yerine getirilir. Cahillerle yapılacak sohbet, güzel ahlak, sabır, idare etme, tahammül, rahmet nazarıyla bakma suretiyle gerçekleşir. Aile efradı ile olan sohbet onlara şefkatle davranarak tedip etme ve böylece onları âyette ${ }^{41}$ ifâde edildiği gibi cehennem ateşinden koruma suretiyle gerçekleşir. İhvân ile sohbet, mümkün olduğunca onlara muvafakat etmek ve şeriata aykırı olmadıkları müddetçe onlara muhalefet etmemek, haset etmemek ve kin gütmemek ile yürütülür. Yöneticilerle sohbet, Allah'ın emir ve yasaklarına, sünnete aykırı olmadığı müddetçe onları dinleme ve itaat etme şeklinde icra edilir. Eğer hükümdar zalim ise mümkün olduğunca ondan uzak durmak tavsiye edilir. Böyle kimselere yakınlaşmak ancak nasihat ederek onu doğru yola çekmek için yapılmalıdır. ${ }^{42}$

Bu ilke, sohbetin geniş anlamından hareketle kişinin karşılaşabileceği her seviyeden muhatap ile nasıl muamele edilmesi gerektiğini incelikleriyle ortaya koymaktadır. Bu durum, tasavvufî terbiye kapsamında müridin yalnızca şeyhine ve diğer müridlere karşı değil, hayatı boyunca karşılaşabileceği toplumun çeşitli kesimlerinden her türlü insanla muamelesinin nasıl olacağına dair detaylı bir eğitimden geçtiğini göstermektedir. Bu ilkeler günümüzde uy-

Ebû Hafs es-Sühreverdî, Avârifü'l-maârif, s. 34; Ebü'n-Necîb es-Sühreverdî, Âdâbü'l-mürîdîn.

39 Ebü'n-Necîb es-Sühreverdî, Âdâbü'l-mürîdîn, s. 36-38.

40 Ebû Hafs es-Sühreverdî, Avârifü'l-maârif, s. 237.

41 et-Tahrîm 66/6.

42 Ebü’n-Necîb es-Sühreverdî, Âdâbü’l-mürîdîn, s. 36-38.

ÇÜiFD, 2017, cilt: 17, sayı: 1, ss. 249-276 
gulandığında insanlar arasında nezakete ve karşılıklı anlayışa dayalı seviyeli ilişkilerin yaygınlaşacağı öngörülebilir.

\section{Arkadaşlıkta İstikrar}

Arkadaşığın devamı için her şeyden önce tarafların bunu sürdürme konusunda kararlı olması gerekmektedir. Sûfîler, müridin salih kimselerle arkadaşlığı sürdürme konusunda kararı olmalarını ve böyle kimselerden ayrılmaktan kaçınmaları gerektiğini vurgulamışlardır. ${ }^{43}$ Bunun için arkadaşlığın sürdürülmesinde karşılıklı olarak bazı hususlara riayet etmek zaruri görülmektedir. İhvânın hatalarını görmezden gelmek, gerektiğinde onlara nasihat etmek, mümkün olduğunca ayıplarını örtmek ve onlarda görülen ayıplar hakkında uyarıda bulunmak sağlıklı bir arkadaşığın sürdürülebilmesi için önemli görülmüştür. Samimiyet içermeyen, pamuk ipliğine dayalı arkadaşlıkların ise kısa süreli olması işten bile değildir.

\section{Yumuşak Huyluluk}

Arkadaşlığın sağlıklı bir şekilde sürdürülmesi için tarafların birbirlerine yumuşak davranmaları esastır. Bunun sağlanması ise nefse uymak suretiyle arkadaşların birbirlerine kaba davranma gibi fiillerden kat'î surette kaçınmalarına bağlanmıştır. Ebû Alî er-Rûzbârî (ö. 322/934) "Yüksekte olana kaba davranmak küstahlık, aynı seviyedekine kaba davranmak edebsizlik ve aşağıdakine kaba davranmak ise acziyettir." diyerek mümkün olduğunca kaba davranmaktan kaçınmanın gerekliliğini vurgulamıştır. ${ }^{44}$

\section{Hoşgörü}

Dostun hata ve küçük yanılgılarını affetmek de arkadaşlığın ilkelerinden biridir. Nitekim kişi zaman zaman çeşitli hata ve günahlara düşebilir. Fakat hatasından dönme intimali her zaman bulunmaktadır. Bundan dolayı müride düşen arkadaşına gerekli öğüt ve nasihatte bulunmak ve onu dışlamamak, hatasından dönmesi için çaba sarf etmektir. ${ }^{45}$

Bu bağlamda şu beş şey edebe aykırı görülmektedir.

a. Kendisine ağır gelen ve dolayısıyla sevmediği işleri yapmaya zorlamak

b. Hakkında doğru bilgiye sahip olduğu halde dedikodulara sessiz kalıp razı olmak

Ebû Hafs es-Sühreverdî, Avârifü'l-maârif, s. 239.

Ebû Hafs es-Sühreverdî, Avârifü'l-maârif, s. 239, 240.

45

Bkz. Ebû Tâlib el-Mekkî, Kûtü'-kulûb, II, 366; Gazzâlî, İhyâu ulûmi'd-dîn, II, 248. 
c. Devamlı nereden gelip nereye gittiğini sorgulamak

d. Hakkında tecessüs yapmak (kusurlarını araştırmak)

e. Hakkında tehassüs yapmak (hakkında yayılan haberlere itibar etmek) $)^{46}$

Bu maddelerden de anlaşıldığı gibi sağlıklı bir arkadaşlığın yürütülebilmesi için tarafların birbirlerinin kusurlarını araştırmaması, gıybet, tecessüs ve tehassüsten kaçınması, görülen ayıpların gizlenmesi önemli görülmüştür.

Arkadaşı idare etmek, iyi geçinmek fakat yağcılık yapmamak da arkadaşlığın gereklerindendir. İdare etmek ile yağcılık yapmak birbirine benzemekle birlikte aralarında bazı farkların olduğu ifâde edilmektedir. İdare etmek, arkadaşın iyiliğini ümit etmek, bunun için onunla iyi geçinip ondan gelen kötülüklere tahammül etmektir. Yağcılık ise arzuları tatmin etmek, mevki ve makam elde etmek ve haz elde etme kastıyla yapılmaktadır. ${ }^{47} \mathrm{O}$ halde arkadaşlığı sağlıklı bir şekilde sürdürebilmek adına yağcılığa kaçmadan muhatabın kusurların görmezden gelerek onu hoş görmek önemli bir ilkedir.

12.Insaf

Sûfîlere göre invâna insaf ile yaklaşmak bununla birlikte onlardan insaf beklememek de arkadaşlığın bir gereğidir. Ebû Osman el-Hîrî (ö. 298/910) "Sohbetin hakkı, malı kardeşin ile paylaşman, onun malına tamah etmemen, ona insaflı davranman, ondan insaf beklememen, ona tabi olman fakat onun sana tabi olmasını beklememen, ondan sana gelenleri çok görmen, senden ona gidenleri ise az görmendir." diyerek bu hususu vurgulamaktadır. ${ }^{48}$

İnsaf mevzuunda da olduğu gibi sûfîlerin genel tavırları Allah'tan başka kimseden hiçbir şey beklememektir. Hal böyle olduğunda insanlardan kendilerine karşı işlenebilecek her türlü kötü davranış karşısında sağlam bir şekilde durmaları mümkün olmaktadır. Aynı şekilde yaptıkları iyiliklerin de karşılığını yalnız Allah'tan beklemelerinden dolayı insanlardan gelebilecek vefasızlıklardan asgari düzeyde etkilenmektedirler.

46 Ebû Tâlib el-Mekkî, Kûtü'l-kulûb, II, 383.

47 Ebû Hafs es-Sühreverdî, Avârifü'l-maârif, s. 239, 240.

48 Ebû Hafs es-Sühreverdî, Avârifü'l-maârif, s. 238.

ÇÜiFD, 2017, cilt: 17, sayı: 1, ss. 249-276 


\section{Gerektiğinde Arkadaşı Uyarmak}

Sûfîlere göre arkadaşlığın gereklerinden biri de tarafların eksik ve kusurlu davranışlar konusunda birbirlerini uyarmalarıdır. Nitekim Hz. Peygamber (sas) "Mümin, müminin aynasıdır." 49 buyurmaktadır. Arkadaşın da bir ayna gibi kardeşinin hata ve kusurlarını kendisine bildirmesi söz konusu hataların düzelmesi için önemli bir husustur. Bunun için mü'min, arkadaşının eksiklerini görmesini sağlamalı, onların düzeltilmesi ve güzel şekle bürünmesi için elinden geleni yapmalıdır. Hz. Ömer "Bana ayıbımı gösteren kimseye Allah rahmet etsin." buyurarak hataları uygun şekilde karşı tarafa bildirmenin önemini vurgulamıştır. 50

Burada şu hususu belirtmemiz gerekmektedir ki arkadaşlara yapılacak uyarılarda muhatabın durumu ve konumu dikkate alınmalıdır. Sûfîlere göre kişinin kendi astı konumunda olan, yani sözünü dinleyebilecek mevkideki kimseleri uyarması tesirli olacaktır. Fakat aynı seviyedekilerin birbirlerini ikaz etmesi hatta kişinin kendinden yüksek mertebede olanları uyarması her zaman için olumlu karşılanmayacaktır. Bundan dolayı karşı tarafın razı olmaması ve kulak asmaması böylece arada soğukluk veya dargınlık oluşması intimaline karşı kusurların tevil edilerek görmezden gelinmesi uygun olacaktır. ${ }^{51}$

Sûfîlere göre kişi eğer sözünde sadık ve samimi ise uyarılması hoşuna gidecektir. Fakat yalancı ise kendisine öğüt verilmesinden rahatsız olacak ve yapılan uyarılar boşa çıkacaktır. Şu durumda arkadaşın samimi olmadığı da görülecektir. ${ }^{22} \mathrm{~Hz}$. Ömer'in "Bana ayıbımı gösteren kimseye Allah rahmet etsin.” sözü uyarıların olumlu bir şekilde karşılanmasının büyük bir erdem olduğunu göstermektedir. Tâbiînden Meymûn b. Mihrân (ö. 117/735) "Benim hoşlanmayacağım şeyi yüzüme söyle. Zira insan sevmediği şeyi yüzüne karşı söylemediği müddetçe gerçekten samimi olmaz. Sadık kimse kedisine doğruyu söyleyeni sever. Yalancı ise samimi olanı sevmez." dedikten sonra "Fakat siz nasihat edenleri sevmiyorsunuz." âyetine ${ }^{53}$ işarette bulunmaktadır. ${ }^{54}$

\footnotetext{
49 Ebû Dâvûd, Edeb, 49, no. 4918.

Ebü'n-Necîb es-Sühreverdî, Âdâbü'l-mürîdîn, s. 35.

Kuşeyrî, er-Risâle, s. 325.

Ebû Tâlib el-Mekkî, Kûtü'l-kulûb, II, 370; Ebû Hafs es-Sühreverdî, Avârifü'l-maârif, s. 236 .

53 el-A'râf 7/79.

54

Ebû Hafs es-Sühreverdî, Avârifü'l-maârif, s. 236.
} 
Arkadaşların uyarılmasında karşı tarafın incinmemesi için gayet nazik ve gizli bir şekilde yapılması gerektiği sûfîler tarafından ayrıca vurgulanmaktadır. Aksi takdirde bu uyarılar, arkadaş ile aranın açılmasına sebep olacaktır. ${ }^{55}$

Sûfîlerin bu ilkeyle vurguladıkları husus, arkadaşlıkta tarafların birbirlerine daima ıslah edici, daha iyiye sevk edici, ayıp ve kusurları mümkün olduğunca yok edici bir tavırla muamele etmelerinin gerektiğidir. Burada karşı tarafın halinin daima göz önünde bulundurulması, kişinin adeta psikolog edasıyla karış tarafla olan muameleleri düzenlemesi gerektiğini göstermektedir. Bu yönüyle sûfîlerin insan psikolojisi konusunda ince bir anlayış sahibi oldukları sezilmektedir.

\section{Diğerkâmlık}

Sûfîlere göre gerçek arkadaşlık ancak kişinin arkadaşını kedisine tercih etmesiyle mümkün olabilir. Kişinin arkadaşını kendisine tercih etmesi özellikle maddî konularda tezahür etmektedir. Gazzâlî, arkadaşların birbirlerinin malı üzerinde hakkı olduğunu ve bu hakkın üç derece halinde karşılanacağını belirtmektedir. En aşağı derece, arkadaşın bir ihtiyacı olduğunda istemesine fırsat vermeden hemen bu ihtiyacı karşılamaktır. İkinci derecesi, arkadaşın adeta mal üzerinde eşit derecede ortaklığı varmış gibi düşünerek gerektiğinde malı onunla bölüşmektir. En üst derecesi ise kişinin arkadaşını kendisine tercih etmesidir (îsâr). Gazzâlî, bu üç dereceden hiç birisine uygun olmayan bir arkadaşlığın hakiki anlamda bir arkadaşlık olmadığını belirtmektedir. ${ }^{56}$ Zira tasavvufta müridin, hiçbir şeyi kendi mülkü olarak görmeyip her şeyin hakikat itibariyle Allah'ın kendisine emaneti olarak görmesi esastır. Mürid bunun şuuruna erdiğinde kendisine ait her türlü eşyayı arkadaşları ile rahat bir şekilde paylaşabilecek, mala mülke gönlünü bağlamayacaktır. ${ }^{57}$ Elindekileri sahiplenmediği için paylaşması da kolay olacaktır. Bu bağlamda sûfîler dünyalığa düşkün olan kimselerle arkadaşlık yapmaktan kaçınılması gerektiğini vurgulamışlardır. Ayrıca "Öyle ise bizim zikrimizden yüz çeviren ve dünya hayatından başka bir şey istemeyen kimselerden yüz çevir."58 âyetinin de buna işaret ettiğini belirtmişlerdir. ${ }^{59}$ İbrahim b. Şeybân (ö. 330/941), "benim ayakkabım"

55 Ebû Tâlib el-Mekkî, Kûtü'l-kulûb, II, 370; Ebû Hafs es-Sühreverdî, Avârifü'l-maârif, s. 236.

56 Gazzâlî, İhyâu ulûmi'd-dîn, II, 235.

57 Ebû Hafs es-Sühreverdî, Avârifü'l-maârif, s. 236.

58 en-Necm 53/29.

59 Ebû Hafs es-Sühreverdî, Avârifü'l-maârif, s. 237.

ÇÜiFD, 2017, cilt: 17, sayı: 1, ss. 249-276 
gibi ifadelerle mal ve mülkü kendilerine nisbet edenler ile arkadaşlık yapılmayacağını bildirmiştir. ${ }^{60}$ Ebû Kasım el-Cürcânî̀ye sohbetin esası sorulduğunda "Hazzını (ve itibarını) sohbette arama." demiştir. "Zira arkadaşıktaki tüm âfetlerin kaynağı; herkesin sohbette kendi haz ve zevkini talep etmesidir. Bir kimse kedi hazzından feragat eder ve yoldaşının hazzına riayet ederse işte 0 vakit sohbette isabet etmiş olur." 61

Öte yandan gerçek manada arkadaşlık eden kimsenin arkadaşına hiçbir konuda haset etmemesi, hatta dini ve dünyevî her türlü meselede onu

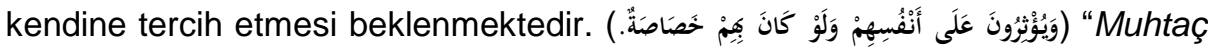
durumda olsalar bile onları kendilerine tercih ederler." ${ }^{2} \mathrm{Bu}$ ayete göre insan Allah için sevdiği kardeşini kendisine tercih etmeli, ihtiyacı olduğu halde malını ona vermelidir. Sûfîlere göre bu, sıddîklerin makamında olanlar içindir. Bu seviyede olmayan kişi en azından malını onunla paylaşmalıdır. Zira bu davranış, sıddîklerin fedakârlığı seviyesinde olmasa da genel olarak mü'minlerin edinmesi gereken bir ahlâkî vasıftır. Ayrıca bazı sûfîlerce mü'minin din kardeşini ailesinden ve çocuklarından da önde tutması tavsiye edilmektedir. Nitekim eş ve çocuklar dünyevî bir sevgiyle sevilmektedir. Buna karşın arkadaş ise sırf Allah rızası için sevildiğinden doğrudan ahirete müteallik bir sevgiye sahiptir. ${ }^{63}$

Başta Gazzâlî olmak üzere sûfîlerin özellikle mal konusunda arkadaşlarını kendilerine tercih etmeleri gerektiği hususu, dünyaya karşı zâhidliğin ileri bir boyutu olarak karşımıza çıkmaktadır. İhtiyaçları karşılamanın bugün dahi arkadaşların birbirleri için rahatlıkla gerçekleştirebilecekleri bir davranış olduğunu söyleyebiliriz. Fakat mal varlığının yarısının veya tamamının arkadaşın olduğunu veya onda ortak olduğunu düşünmek benimsenmesi çok zor bir fiil gibi gözükmektedir. Bununa birlikte Hz. Peygamber ile ashabı ve özellikle ensar ve muhacirler arsındaki ilişki düşünüldüğünde kişinin arkadaşını kendisine tercih etmesi gerçekten fedakârca ve zor bir davranış olsa da imkânsız olmadığı anlaşılmaktadır. ${ }^{64} \mathrm{Bu}$ bakımdan tasavvuftaki bu ilkenin sadece sûfîlerin değil, gerçek anlamda bir dostluk ilişkisi kurmak isteyen herkesin örnek alması gereken ilkelerden olduğunu söyleyebiliriz.

60 Gazzâlî, Ihyâu ulûmi'd-dîn, II, 236; Ebû Hafs es-Sühreverdî, Avârifü'l-maârif, s. 236.

61 Hücvîrî, Keşfu'l-mahcûb (Hakikat Bilgisi), s. 401.

62 el-Haşr 59/9.

63 Ebû Tâlib el-Mekkî, Kûtü'l-kulûb, II, 369.

64

Sancar, "Gazâlî Düşüncesinde Kardeşlik ve Kardeşlik Hakları", s. 204. 


\section{Arkadaşın Ihtiyacını Gidermek}

Arkadaşların birbirleri üzerindeki haklarından birisi de her türlü ihtiyacın karşılanması hususunda yardımlaşmaktır. Kişinin arkadaşına yardım etmesi, onu maddeten ve mânen desteklemesi arkadaşlığın gereklerinden biridir. Arkadaşa yapılacak yardım; ihtiyacı olduğunda bedenen, kendisine haksızlık edildiğinde sözle ve muhtaç olduğunda mali olarak gerçekleşebilir. Bunların dışında sıkıntılı zamanlarında kendisine inanıp güvenmek suretiyle kalben de gerçekleştirilebilir. ${ }^{65}$ Bunun gerçekleştirilmesi için kişi arkadaşının intiyacını kendi ihtiyacı olarak görmeli, kendi ihtiyaçlarını unutmadığı gibi arkadaşının ihtiyaçlarını da araştırıp tespit etmelidir. Bu bağlamda arkadaş bir şeye ihtiyaç duyduğunda, daha o istemeden yardım etmek suretiyle ihtiyacın giderilmesi temel ilkedir. İstenmeden ihtiyacın görülüp yerine getirilmesi vurgulanırken arkadaşın bir ihtiyacını arz ettiği zaman onu güzellikle yerine getirmenin arkadaşığın en aşağı derecesi olduğu da ifâde edilmektedir. ${ }^{66}$

\section{Eziyet Etmekten Kaçınmak}

Lüzumsuz isteklerde bulunarak yük olmamak arkadaşlığın bir gereğidir. Hatta yük olmamak gayesiyle arkadaştan intiyacı mümkün olduğunca gizlemenin daha uygun olacağı sûfîlerce kabul edilmektedir. Bu bağlamda "Kendisinden beklenmeyeni arkadaşlarından bekleyen onlara zulmetmiş olur. Kendisinden bekleneni arkadaşlarından da bekleyen onları yormuş olur. Kimseden bir şey beklemeyen ise arkadaşlarına fazilet göstermiş olur." denilmiştir. 67

Hz. Ali'ye atfedilen "Arkadaşın şerlisi seni kendisini idare etmeye muhtaç eden, özür dilemek durumunda olan ve seni sıkıntıya sokandır." 68 sözü sûfîlerin bu konudaki temel saikleri olmuştur. Buradan hareketle arkadaşlarını, kendisini idare etmek ve ondan özür dilemek zorunda bırakmamak, onları sıkıntıya sokmamak, tam aksine onların isteklerini kendi isteklerine tercih etmek prensip haline getirilmiştir.

\footnotetext{
65 Ebû Tâlib el-Mekkî, Kûtü'l-kulûb, II, 371.

67 Ebû Tâlib el-Mekkî, Kûtü'l-kulûb, II, 365; Gazzâlî, İhyâu ulûmi'd-dîn, II, 255. 
Öte yandan müridin, arkadaşlarının hizmetine koşması, sıkıntılarını gidermesi, dine muhalefet etmediği müddetçe isteklerini yerine getirmesi ve onlardan gelecek her türlü eziyete tahammül etmesi tavsiye edilmiştir. ${ }^{69}$

\section{Dua ve Af Dileme}

Hayattayken arkadaşın gıyabında istiğfarda bulunmak, onlardaki çirkinlikleri gidermesi için, öldükten sonra da günahlarının affı için Allah'a dua etmek de arkadaşlığın gerektirdiği bir vazifedir. ${ }^{70}$ Zünnûn el-Mısrî’ye (ö. 245/859) kiminle arkadaşlık yapılır diye sorulduğunda "Hastalandığın zaman seni ziyarete gelen ve günah işlediğinde ise senin için tevbe eden kimse ile" diyerek cevap vermiştir. ${ }^{71}$

Yahyâ b. Muâz er-Râzî (ö. 258/872), dost olan kimseye "Allah'a dua ettiğinde beni de hatırla." demeye ihtiyaç duymayı bir kusur olarak görmektedir. Nitekim ona göre bir saatlik bile samimi dostluk kurmuş olmanın bir ömür boyu dua edilmesine bedel olabilecek kadar kıymetli olduğunu belirtmektedir. Râzî’ye göre yapılan hatalar neticesinde özür beklemek bile samimiyetsizlik ve aradaki soğukluktan ileri gelir. Samimi dostluklarda hataları hoş görmek esastır. ${ }^{72}$

\section{Edeb}

Arkadaşlığın devamlıığının sağlanmasında müridin bazı edeblere riayet etmesi gerekmektedir. Sûfîler ihvan ile münasebetlerinde vücuttaki her bir organ için bazı edeb kaideleri olduğundan bahsetmektedirler. Söz gelimi gözün edebi haramlara bakmamak ve genel olarak insanların ve özelde ihvanın ayıp ve kusurlarını görmemektir. Bunun yanında dostlara daima şefkat nazarı ve ibretle bakmak, ayrıca konuşurken de gözleri onlardan ayırmamak gözün edebleri arasında sayılmaktadır.

Dilin edebi, daima Allah'ı zikretmek, ihvanı arkalarından hayır ve dua ile anmak, gerektiğinde onlara nasihat etmek ve kendileriyle hoşlanmayacakları şekilde konuşmamaktır. Bunun yanında gıybet etmemek, insanların arasını bozmamak, sövmemek, mâlâyânîye dalmamak, alçak sesle ve muhatabın

69 Ebû Hafs es-Sühreverdî, Avârifü'l-maârif, s. 236; Ebü'n-Necîb es-Sühreverdî, Âdâbü'l-mürîdîn, s. 35.

70 Gazzâlî, Ihyâu ulûmi'd-dîn, II, 252; Ebû Hafs es-Sühreverdî, Avârifü'l-maârif, s. 239, 240.

71 Kuşeyrî, er-Risâle, s. 328.

72 Hücvîrî, Keşfu'l-mahcûb (Hakikat Bilgisi), s. 399. 
anlayacağı şekilde konuşmak da kişinin konuşmasında dikkat edeceği hususlar arasında sayılmaktadır.

Dinlemenin edebi çirkin ve günah içeren sözleri, gıybet ve nemime gibi kötü konuşmaları işitmemek, bunların yerine zikir, vaaz ve hikmet gibi faydalı şeyleri dinlemektir. Ayrıca dostlarla görüşürken onları can kulağı ile inanarak ve güvenerek dinlemek, ona itiraz ederek sözünü kesmemek de bu kapsamda mütalaa edilmektedir.

Ellerin edebi, arkadaşlara el ile yapılabilecek yardımdan geri durmamak, onlara daima insanda bulunmak, hizmet etmek ve yasaklar hususunda yardımlaşmamaktır.

Ayakların edebi, arkadaşların iyiliği için koşturmak, yeryüzünde kibirlenerek yürümemektir. Bunun yanında yürürken arkadaşların arkasında yürümek, misafir olarak geldiklerinde ayakta karşılamak, onlar oturmadan oturmamak da bu kapsamda sayılmaktadır. ${ }^{73}$

Kalbin edebi ise kötü düşünceleri zihinden atarak güzel düşünceleri yerleştirmek; Allah'ın yüceliğini, nimetlerini ve yaratmasındaki muhteşemliği düşünmektir. ${ }^{74}$

Edeb kapsamında sayılanlar esas itibariyle arkadaşlık ve dostluk için saydığımız temel ilkelerin azalar üzerinde dağılmış hali gibidir. Arkadaşın ayıp ve kusurlarını görmemek, onlara hoşgörüyle yaklaşmak, onlarla güzel konuşmak, tevâzû ile yaklaşmak... İşte bu ilkeler organlar vasıtasıyla hayata geçirildiğinde arkadaşlık sağlam temeller üzerine oturacak ve süreklilik kazanacaktır.

\section{Dile Sahip Olmak}

Mürid arkadaşı hakkında ne zaman konuşup ne zaman susması gerektiğini bilmelidir. Öncelikle arkadaşının gıyabında, aleyhinde olacak şekilde konuşmamalı, gıybet etmemeli, ayıp ve kusurunu biliyorsa dahi susmalı ve bunları ifşâ etmemelidir. Yine yolda arkadaşı ile karşılaştığı zaman nereden gelip nereye gittiğini sormamalıdır. Nitekim gereksiz sorular yöneltildiğinde, açıklama yapmak istemeyen kimse yalan söylemek durumunda kalabilecektir. ${ }^{75} \mathrm{Bu}$ intimale binâen mümkün olduğunca soru sorulmaması tavsiye edilmektedir. Öte yandan aralarındaki sırları başkalarına açmamaları da arkadaş-

73 Gazzâlî, İhyâu ulûmi'd-dîn, II, 258, 259; Ebü’n-Necîb es-Sühreverdî, Âdâbü'lmürîdîn, s. 38-40.

74 Ebü'n-Necîb es-Sühreverdî, Âdâbü'-mürîdîn, s. 40.

75 Ebû Tâlib el-Mekkî, Kûtü'l-kulûb, II, 383.

ÇÜiFD, 2017, cilt: 17, sayı: 1, ss. 249-276 
lık âdâbındandır. Özetle kişi arkadaşının hoşlanmayacağı her türlü sözden kaçınmalı, mümkün olduğunca ona muhalefet ve itiraz etmemelidir. ${ }^{76}$ Fakat bunun bir istisnasından da bahsedilmektedir ki o da emr-i maruf ve nehy-i münker bağlamında arkadaşı ikaz sadedinde yapılan konuşmalar bu kapsama girmemektedir. Zira bu durum karşı tarafın menfaatine olan uyarılardan oluşmaktadır. ${ }^{77}$ Karşı taraf memnun olmayacaksa bile onun bazı ayıp ve kusurlarını ortadan kaldırmak adına ikaz edilmesi arkadaşığın bir gereği olacaktır.

\section{Güzel Söz}

Yeri geldiğinde susmak arkadaşlığın bir gereği olduğu gibi yeri geldiğinde de güzel söz ile muhabbet etmek arkadaşlı̆ın icap ettirdiği bir haldir. Arkadaşın halini, hatıını sormak ve mutlulukları paylaşmak da arkadaşığın

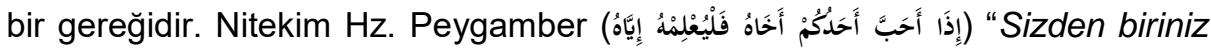
kardeşini sevdiğinde, sevdiğini kendisine duyursun." ${ }^{8}$ buyurarak mü'minlerin sevgilerini dile getirmelerini tavsiye etmektedir. Böylece aradaki muhabbetin çoğalması hedeflenmektedir. ${ }^{79}$

Konuşmanın gerekli olduğu zamanlardan biri de kişinin övülmeyi arzu edebileceği yerlerde onun iyi yönlerini dile getirmektir. Nitekim bu şekilde muhatabın sevgisini celp etmek kolay olacaktır. Yine kişinin ailesini, çocuklarını, ahlâkını, kıyafetini, sözlerini yalan söylememek suretiyle övmek de aradaki muhabbeti arttıracağı için tavsiye edilmektedir. Bunun yanında arkadaşa teşekkür etmek, ilim öğretmek, öğüt vermek ve yahut gıyabında ona yöneltilen ithamlara karşı kendisini savunmak için konuşmak zorunluluk arz etmektedir. ${ }^{80}$

\section{Vefâ}

Müslüman kardeşine karşı vefâlı olmalı, kendisiyle ölünceye kadar dost olarak kalmalı, vefatının ardından ise aile efradına karşı dostluğun gereklerini yerine getirmelidir. Sûfîlere göre arkadaşın dost ve akrabalarını arayıp sormak ve onlarla ilgilenmek vefânın ilk şeklidir. İkinci şekli, kişi hangi mertebeye yükselirse yükselsin dostu ile tevazu içerisinde muamele etmesi ve ha-

76 Ebû Tâlib el-Mekkî, Kûtül-kulûb, II, 374.

77 Gazzâlî, İhyâu ulûmi'd-dîn, II, 239.

78 Tirmizî, Zühd, 54, no. 2392. Ayrıca bkz. Ebû Dâvûd, Edeb, 112-113, no. 5125.

79 Tasavvufta muhabbet kavramı ile ilgili bkz. Mansur Gökcan, "Havf ve Recâ (Korku ve Ümit) Dengesi”, Çukurova Üniversitesi Illahiyat Fakültesi Dergisi, XVI/2 (2016): 175.

80 Gazzâlî, Ihyâu ulûmi'd-dîn, II, 245-248. 
linde hiçbir değişiklik bulunmamasıdır. Vefânın şekillerinden birisi de dost ile ayrı kalmaktan son derece üzülmek ve ayrılığı gerektirecek durumlardan nefret etmektir. Son olarak dostun düşmanı ile dostluk kurmamaktır. ${ }^{81}$

\section{Sonuç}

Mürid-mürşid ve ihvanlar arası ilişkilerini Hz. Peygamber ile ashabı arasındaki yakın ilişkiye dayandıran sûfîler dostluklarını sohbet ve uhuvvet anlayışı üzerine şekillendirmişlerdir. Onlar, sağlıklı arkadaşlığın tesisi ve devamlılığını, âyet ve hadislerden yaptıkları çıkarımlara kişisel kanaat ve tecrübelerini de ilave etmek sûretiyle tespit ettikleri âdâb ve erkâna uyulmasına bağlamışlardır.

Tasavvuf klasikleri bağlamında tespit ettiğimiz ilkeler düşünüldüğünde sûfîlerin arkadaşlıkta önem verdikleri ilk ve en önemli maddenin doğru arkadaş tercihi olduğu görülmektedir. Sûfilere göre arkadaşın sağlam bir itikada sahip, dinin emir ve yasaklarına tabi ve güzel ahlâklı olması zorunluluk arz etmektedir. İsabetli bir arkadaş tercihinin ardından samimiyet, ihlas, güven ve şefkat temelli kurulan arkadaşlıkta taraflara düşen kararlı bir şekilde arkadaşIığı sürdürmektir. Bunun için tarafların hoşgörülü, insaflı, paylaşımcı, karşı tarafı düşünen bir arkadaş modeli sergilemesi her şeyin önünde gelmektedir. Bu şekilde kurulup sürdürülen bir arkadaşığın devamlı olacağı öngörülmektedir.

Sûfîlerin tesis etmiş oldukları arkadaşlıkta dikkat çeken önemli bir husus da zühd merkezli bir dostluk modelinin öne çıkarılmasıdır. Sûfîlere göre kişi dünyalığa önem vermemesi dolayısıyla her durumda maddeten ve mânen arkadaşını kendisine tercih edebilmelidir. Zira arkadaşlık yalnızca Allah rızası için kurulduğundan bu ilişkide maddi bir beklenti söz konusu olmayacaktır. Kişinin, mal varlığında arkadaşını ortak olarak görmesi, hatta tüm varlığının asıl itibariyle kendisine ait olmadığını düşünmesi ilk bakışta uygulanması mümkün olmayan hayalî bir düşünce gibi gelse de Hz. Peygamber ve ashabının yaşantısı düşünüldüğünde ve özellikle ensar ve muhacirler arasındaki ilişki göz önünde bulundurulduğunda hayata geçirilmesinin çok da uzak bir intimal olmadığı anlaşılacaktır. Buna rağmen ortalama bir mü'min için aşırı olduğu düşünülebilecek zühd ile ilgili bazı hususlar dışarıda bırakılacak olursa, asırlar önce sûfîler tarafından ortaya konulan bu ilkelerin, yalnızca kendi zamanlarına değil günümüze de hitap eden prensipler olduğu görülmektedir. Söz konusu ilkeler arasında, gerek tasavvuf yolunda ilerlemek iradesini göste-

Bkz. Gazzâlî, Ihyâu ulûmi'd-dîn, II, 253-255. 
ren müridler gerekse tasavvufî çevrenin dışında müslüman olsun ya da olmasın sağlıklı dostluk ve arkadaşlık ilişkilerini tesis etmek isteyen herkesin benimseyebileceği evrensel ilkelerin yer aldığını söylemek mümkündür.

\section{Kaynakça}

Akot, Bülent, "Tasavvufî İrşad Metodu Olarak Sohbetin Fonksiyonu = Function of Gabfest as Sufistic Guidance Method", Uluslararası Sosyal Araştırmalar Dergisi = The Journal of International Social Research, VII/31 (2014), ss. 30-39.

Altunbay, Müzeyyen, "Erzurumlu İbrahim Hakkı Hazretleri ve Marifetnâme'de Sohbet Adabı", Bütün Yönleriyle Erzurumlu Ibrahim Hakkı Hazretleri Sempozyumu (16-18 Kasım 2011 Erzurum) Bildiriler, 2012, ss. 95-104.

Arpaguş, Safi, “Alvarlı Hâce Muhammed Lutfî̀nin Dîvân'ında Bir Seyr u Sülûk Metodu Olarak Sohbet", Uluslararası Hâce Muhammed Lutfî (Alvarlı Efe) Sempozyumu (25-26 Nisan 2013, Erzurum) Bildiriler, 2013, ss. 539-548.

—_, "Tasavvuf Kültüründe Kardeşlik Algısı", Kutlu Doğum Haftası "Hz. Peygamber Kardeşlik Ahlakı ve Kardeşlik Hukuku” Sempozyumu (2122 Nisan 2012), (2013), ss. 432-441.

Cürcânî, Ebü'l-Hasan Seyyid Şerif Ali b. Muhammed b. Ali, Mu'cemü't-ta'rîfât, haz. Muhammed Sıddîk el-Münşâvî, Kahire: Muhammed Sıddîk elMünşâvî, ty.

Ebû Hafs es-Sühreverdî, Şehabeddin Ömer b. Muhammed, Avârifü'l-maârif, Beyrut: Dâru Sâdır, 2010.

Ebû Tâlib el-Mekkî, Muhammed b. Ali b. Atıyye el-Hârisî Kûtü'l-kulûb fî muâmeleti'l-mahbûb ve vasfu tarîki'l-mürid ilâ makami't-tevhid, haz. Asım İbrâhim el-Keyyâlî el-Hüseynî eş-Şâzelî ed-Derkâvî, I-II, Beyrut: Dâru'l-Kütübi'l-İlmiyye, 2009.

Ebü'n-Necîb es-Sühreverdî, Ziyâüddîn Abdülkahir b. Abdillâh, Âdâbü'lmürîdîn, haz. Asım İbrahim el-Keyyâlî, Beyrut: Dâru'l-Kütübi'l-İımiyye, 2013.

Erkaya, Mahmud Esad, Kur'an Kaynaklı Tasavvuf Kavramları, Ankara: Otto, 2017.

Erul, Bünyamin, Sahabenin Sünnet Anlayışı, Ankara: Türkiye Diyanet Vakfı Yay., 2005.

Gazzâlî, Ebû Hamid Huccetülislâm Muhammed b. Muhammed, İhyâu ulûmi'ddîn, I-V, Beyrut: Mektebetü'I-Asriyye, 2013. 
Gökbulut, Süleyman, “Ebu'n-Necîb Ziyâüddîn es-Sühreverdî ve Âdâbü'lMürîdîn Adlı Eseri”, Dokuz Eylül Üniversitesi IIlahiyat Fakültesi Dergisi, 28 (2008), ss. 135-152.

Gökcan, Mansur, "Havf ve Recâ (Korku ve Ümit) Dengesi”, Çukurova Üniversitesi Illahiyat Fakültesi Dergisi, XVI/2 (2016), ss. 171-192.

Halil b. Ahmed, Kitâbü'l-ayn, haz. Abdülhamid Hindâvî, I-IV, Beyrut: Dâru'lKütübi'l-İlmiyye, 2003.

Hücvîrî, Ebü'l-Hasen, Keşfu'l-mahcûb (Hakikat Bilgisi), çev. Süleyman Uludağ, İstanbul: Dergâh, 2010.

İbn Manzûr, Ebü'l-Fazl Muhammed b. Mükerrem b. Ali el-Ensârî, Lisânü'lArab, haz. Abdullah Ali Kebir, Muhammed Ahmed Hasbullah - Hâşim Muhammed eş-Şâzelî, I-VI, Kahire: Dâru'l-maârif, ty.

Kuşeyrî, Ebü'l-Kâsım Zeynülislâm Abdülkerîm b. Hevâzin, er-Risâletü'lKuşeyriyye, haz. Halil el-Mansûr, Beyrut: Daru'l-Kütübi'l-İlmiyye, $1422 / 2001$.

Ögke, Ahmet, "Oğlanlar Şeyhi İbrâhim Efendi'ye Göre Sohbet Âdâbı", İslâmî Araştırmalar Dergisi, XVII/1 (2004), ss. 84-90.

Râgıb el-İsfahânî, Ebü'l-Kāsım Hüseyn b. Muhammed b. el-Mufaddal, elMüfredât fî garîbi'l-Kur'ân, haz. Safvân Adnân ed-Dâvûdî, Beyrut: Dâru'l-Kalem, 1412.

Sancar, Faruk, "Gazâlî Düşüncesinde Kardeşlik ve Kardeşlik Hakları”, Kutlu Doğum Haftası "Hz. Peygamber Kardeşlik Ahlakı ve Kardeşlik Hukuku" Sempozyumu (21-22 Nisan 2012), (2013), ss. 200-212.

Serrâc, Ebû Nasr Abdullah b. Ali et-Tûsî, el-Lüma'fî târîhi't-Tasavvufi'l-İslâmî, haz. Kamil Mustafa el-Hindâvî, Beyrut: Dâru'l-Kütübi'l-İlmiyye, 2007.

Tehânevî, Muhammed b. A'lâ b. Ali el-Fârukî el-Hanefî Mevsûatü keşşâfi Istılâhâti'l-fünûn ve'l-ulûm, haz. Refîk el-Acem, I-II, Beyrut: Mektebetu Lübnan [Librairie du Liban], 1996.

Uludağ, Süleyman, "Âdâbü'l-mürîd”, TDV İslâm Ansiklopedisi (DIA), 1988, I.

—, "İhvan", TDV İslâm Ansiklopedisi (DIA), İstanbul 2000, XXI.

—, "Sohbet", TDV İslâm Ansiklopedisi (DIA), İstanbul 2009, XXXVII, 350351. 


\section{Basic Principles of Religious Conversations (Sohbet) and Brotherhood (Uhuvvet) in the Main Sufi Classical Books}

Citation / ( - Erkaya, M. E. (2017). Basic Principles of Religious Conversations (Sohbet) and Brotherhood (Uhuvvet) in the Main Sufi Classical Books, Çukurova University Journal of Faculty of Divinity, 17 (1), 249-276.

Abstract- According to some sufis, Sufism is entirely composed of the good manners (âdâb). Therefore the moral codes regulating a person's environment and their relationship with the Allah has constituted an important place in the literature of Sufism. In main sufi classical books, many good manners are defined, such as the worship, expedition (sefer), accommodation (ikamet), peer-to-peer relationships, whirl (sema), cleaning, eating, drinking, clothing, and hospitality. Religious conversation (sohbet) and brotherhood (uhuvvet) are also the important issues in these books. The concept of sohbet is used in two meaning: The first meaning is companionship, based on love and understanding between individuals. The second meaning is conversation. Essentially in Sufi education sohbet method is carried out. This method is based on the companionship between the Prophet and his companions. Therefore, the boundaries and manners of the relationship between murid and murshid have been mentioned in sufi sources in details. On the other hand, the good manners of friendship of murids with each other have been formed by determining some basic principles. In this context, many topics have been addressed in the main Sufi classical books such as how to choose right friend, the purpose and characteristics of ideal friendship and method of communication with friends. In this paper, we will explain the relationship of Sufis to each other and society in the context of companionship and the fellowship.

Keywords- Companionship, fellowship, sufism, uhuvvet 